\title{
Bruk av GnRH-antagonist ved in vitro-fertilisering
}

\begin{abstract}
Sammendrag
Bakgrunn. Den tradisjonelle behandlingsmetoden ved in vitro-fertilisering (IVF), der man benytter GnRH-agonist for å hindre prematur eggløsning, kan for mange pasienter innebære en stor psykisk og fysisk belastning. En alternativ behandlingsmetode er å anvende $\mathrm{GnRH}$-antagonist. Målet med artikkelen er å beskrive fordeler og ulemper ved bruk av $\mathrm{GnRH}$-antagonist ved in vitro-fertilisering.
\end{abstract}

Materiale og metode. Artikkelen er basert på mer enn ti års erfaring med bruk av gonadotropinfrigjørende hormonantagonist (GnRH-antagonist) ved in vitro-fertilisering. Dessuten er det foretatt ikke-systematiske $s ø k$ i PubMed.

Resultater. Ved å anvende lavere doser av follikkelstimulerende hormon (FSH) for å stimulere eggstokkene enn det som har vært vanlig, samtidig som man starter med GnRH-antagonist på et tidlig tidspunkt, forblir graviditetsfrekvensen like høy som når en GnRHagonist benyttes. En mindre intensiv stimulering innebærer redusert risiko for bivirkninger og komplikasjoner. Behandlingstiden frem til egguttak reduseres fra 4-5 uker til mindre enn to uker. Ulempen med bruk av GnRHantagonist er hovedsaklig at stimuleringsstart ikke kan styres i samme grad som ved bruk av $\mathrm{GnRH}$-agonist.

Fortolkning. Stimulering med GnRHantagonist ved in vitro-fertilisering medfører mindre psykisk og fysisk belastning for pasientene uten at fødselsraten reduseres.

\section{Erling Ekerhovd}

erling.ekerhovd@obgyn.gu.se

Medicus

Trondheim

og

Sahlgrenska akademiet

Göteborgs universitet

Hvert år fødes omtrent 2000 barn i Norge etter in vitro-fertilisering (IVF). I mer enn 20 år har initial nedregulering av eggstokkene ved bruk av gonadotropinfrigjørende hormonagonist (GnRH-agonist) for å hindre prematur eggløsning vært et førstevalg ved in vitro-fertilisering. Ved å variere perioden kvinnene blir behandlet med GnRH-agonist har denne behandlingsstrategien ført til effektiv utnyttelse av behandlingskapasiteten ved fertilitetsklinikkene samtidig som graviditetsfrekvensen har vært høy. Ulempene ved å benytte GnRH-agonist er lang behandlingstid før egguttak og at en del kvinner har bivirkninger fordi behandlingen fører til et lavt østrogennivå. Flere studier har vist at selv om fertilitetsbehandlingen er offentlig finansiert, velger en stor andel av parene som ikke oppnår vellykket graviditet på et tidlig tidspunkt, å avbryte behandlingen dersom en GnRH-agonist blir benyttet (1-5). Selv om årsakene til det høye frafallet er mange, skyldes omtrent en tredel av tilfellene den psykiske og fysiske belastningen behandlingen innebærer (3-6).

Anvendelse av GnRH-antagonist er en alternativ behandlingsstrategi for å hindre prematur eggløsning. Denne strategien medfører ikke et lavt østrogennivå og gir kort behandlingstid før egguthenting, noe som ser ut til å redusere den psykiske og fysiske belastningen $(7,8)$. Flere som jobber med fertilitetsbehandling har derfor tatt til orde for at GnRH-antagonist bør være førstevalg ved in vitro-fertilisering for derved å gjøre behandlingen mer pasientvennlig $(9,10)$.

Målet med denne artikkelen er å belyse ulike aspekter ved bruk av GnRH-antagonist ved in vitro-fertilisering.

\section{Materiale og metode}

Artikkelen er basert på erfaring med klinisk utprøvning av GnRH-antagonist ved in vitro-fertilisering i fase III-studier for mer enn ti år siden og deretter egen klinisk erfaring med regelmessig bruk av GnRH-antagonistene ganirelix og cetrorelix. De siste fire årene har mer enn $90 \%$ av alle kvinner som har gjennomgått in vitro-fertilisering ved de to sentrene der jeg har jobbet, London Fertility Centre i London og Medicus i Trondheim, fått behandling med GnRHantagonist. I tillegg er det foretatt ikkesystematiske litteratursøk i PubMed.

\section{GnRH-agonist}

Behandlingen med GnRH-agonist starter vanligvis en uke før forventet menstruasjon eller på første menstruasjonsdag (fig 1). Initialt resulterer medisineringen i en kort, forbigående gonadotropinstimulering før en hypofysær desensitisering inntreffer med en gradvis suppresjon av gonadotropinsekresjonen. Det lave nivået av gonadotropiner fører til at østrogennivået synker, og eggstokkene er nedregulerte etter 2-3 ukers behandling. Tiden som kvinnene bruker GnRH-agonist tilpasses imidlertid ofte klinikkens behandlingskapasitet, slik at denne perioden kan være lenger. Etter nedreguleringen stimuleres ovariene med follikkelstimulerende hormon (FSH), eventuelt i kombinasjon med luteiniserende hormon (LH), i omtrent 12-14 dager. Samtidig fortsetter behandlingen med GnRH-agonist frem til det gis en injeksjon med humant choriongonadotropin (HCG) for å fullføre sluttmodningen av eggene. Egguthentingen utføres ca. 36 timer etter injeksjonen med HCG. Eggene blir så forsøkt fertilisert. Normalt settes ett eller to embryoer inn i livmorhulen 2-5 dager etter egguthentingen.

\section{GnRH-antagonist}

Ved dette behandlingsregimet startes stimuleringen av eggstokkene med FSH i begynnelsen av menstruasjonssyklusen, der man utnytter og forsterker den naturlige endogene FSH-stigningen som inntreffer ved overgangen til en ny menstruasjonssyklus (fig 1).

\section{Hovedbudskap}

- Anvendelse av GnRH-antagonist ved in vitro-fertilisering resulterer i samme graviditetsfrekvens som ved bruk av GnRH-agonist

- Bruk av GnRH-antagonist ved in vitrofertilisering reduserer pasientens belastningsbyrde

- En mindre intensiv stimulering enn den tradisjonelle gir færre bivirkninger, men samme graviditetsrate 

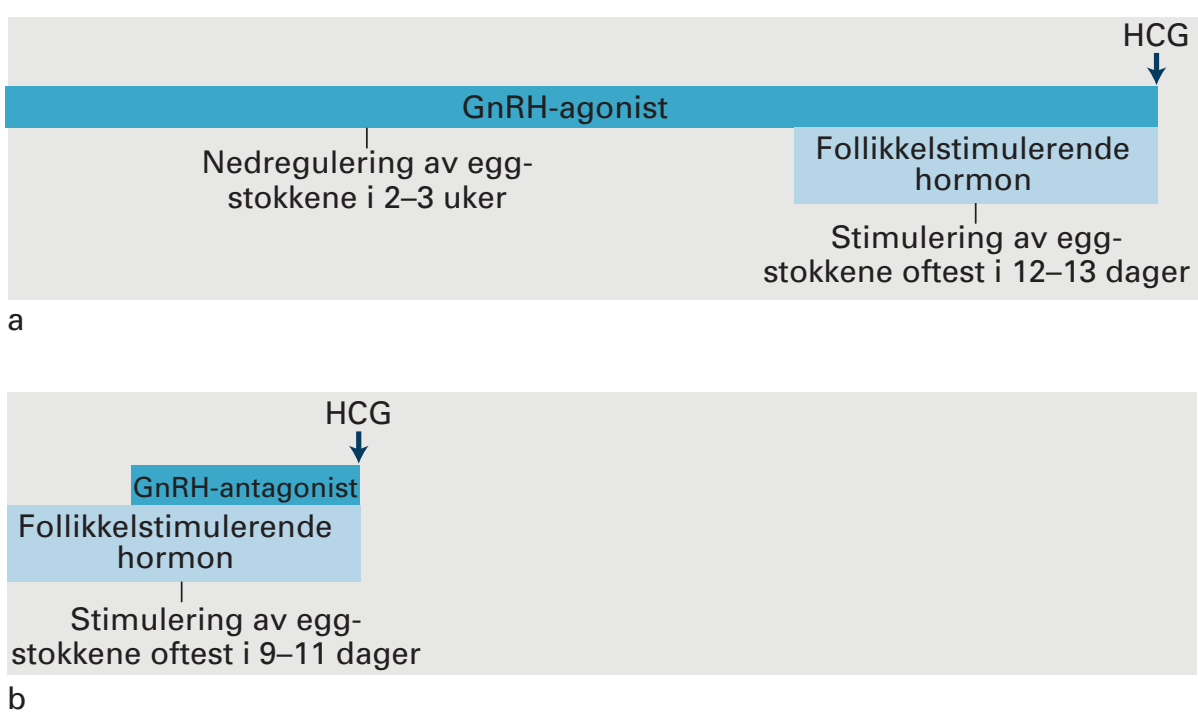

Figur 1 Sammenlikning av behandlingsvarighet før egguttak ved al tradisjonell behandling med GnRH-agonist og b) bruk av GnRH-antagonist ved in vitro-fertilisering. Egguttak utføres ca. 36 timer etter at humant choriongonadotropin (hCG) injiseres subkutant

Oftest begynner man med FSH-injeksjonene på syklusdag 2 eller 3 , men man kan begynne så tidlig som syklusdag 1 eller så sent som syklusdag 6. Generelt sett er det slik at jo tidligere oppstart med FSH-injeksjoner og jo høyere dose som injiseres, desto flere egg vil kunne rekrutteres.

GnRH-antagonistene virker ved kompetitiv binding til GnRH-reseptorene i hypofysen. Endogent GnRH blokkeres allerede 6-8 timer etter behandlingsstart, og LHsekresjonen hemmes derved etter kort behandlingstid.

Når det gjelder starttidspunkt for GnRHantagonist, har det vært anvendt flere stra-

\section{Ramme 1 \\ Fordeler ved bruk av GnRH- antagonist sammenliknet med tradisjonell GnRH-agonistbehandling \\ - Kortere behandlingstid \\ - Redusert bivirkningsrisiko \\ - Redusert komplikasjonsrisiko \\ - Lavere medikamentforbruk \\ - Reduserte behandlingskostnader}

\section{Ramme 2}

Fordeler ved bruk av tradisjonell $\mathrm{GnRH}$-agonistbehandling sammenliknet med GnRH-antagonist

- Større klinisk erfaringsgrunnlag

- Mer fleksibel stimuleringsprotokoll

- Mindre arbeidsbelastning i helgene tegier (11). I dag benyttes som oftest en bestemt syklusdag som starttidspunkt fordi dette er enklere, gir høyere graviditetsrate og innebærer færre ultralydkontroller (12). Det har vært observert at sjansen for graviditet øker om GnRH-antagonistbehandlingen initieres på et tidlig tidspunkt, kanskje allerede fra syklusdag $5(12,13)$. Ved de to siste store GnRH-antagoniststudiene der langtidsvirkende FSH (korifollitropin- $\alpha$ ) ble testet, startet man med GnRH-antagonist fra og med den femte stimuleringsdagen $(14,15)$. Dette er en dag tidligere enn i samtlige av de tidligere store GnRH-antagoniststudiene (16-19). Langtidsvirkende FSH i kombinasjon med GnRH-antagonist innebærer et redusert antall injeksjoner.

Hvor intensivt eggstokkene bør stimuleres for å oppnå best mulig graviditetsrate samtidig som man minimaliserer risikoen for bivirkninger, er fortsatt uavklart. Det er imidlertid klart at stimuleringen alltid bør individualiseres, og at de fleste pasientene ikke trenger å gjennomgå en så intensiv stimulering som tradisjonelt har vært benyttet. Betegnelsen mild in vitro-fertilisering er et eksempel på en stimuleringsvariant der GnRH-antagonist anvendes, men der eggstokkene stimuleres relativt sent i follikkelfasen, oftest fra syklusdag $5 \mathrm{og}$ i regelen med lave doser FSH (20). Ved denne stimuleringsstrategien er målet å høste 2-7 egg. Man antar at denne behandlingen gir egg av god kvalitet, som skal resultere i en høy graviditetsfrekvens samtidig som behandlingen blir så pasientvennlig som mulig $(20,21)$.

\section{Blodprøver}

Som ved bruk av GnRH-agonist er det i de fleste tilfeller ikke nødvendig å måle hormonnivå når man anvender GnRH-antagonist. Blodprøver bør i regelen bare tas i tilfeller der stimuleringen har vist seg vanskelig eller der det har vært utført gjentatte mislykkede behandlinger. Serumnivåene av visse hormoner (progesteron, østradiol og LH) både før stimuleringsstart og under stimuleringen kan imidlertid være av stor prognostisk betydning for visse pasienter $(22-26)$. Eksempelvis vil et høyt progesteronnivå ( $\geq 6,5 \mathrm{nmol} / \mathrm{l}$ ) på syklusdag 2 , noe som oftest skyldes ufullstendig luteolyse, redusere sjansen for vellykket graviditet (22). Høye serumnivå av LH og østradiol i tidlig follikkelfase ser ut til å være forbundet med redusert sjanse for graviditet (23). I sluttfasen av stimuleringen ser det ut til at det er størst mulighet for vellykket graviditet om konsentrasjonen av LH er lav, det vil si $0,1-0,5 \mathrm{IE} / 1$ på syklusdag 10 (24). Prematur luteinisering defineres ofte ved et serumprogesteronnivå over $6,0 \mathrm{nmol} / 1 \mathrm{den}$ dagen HCG injiseres for å sluttføre eggmodningen. En for tidlig luteinisering er assosiert med redusert implantasjonsrate når embryo settes inn i livmoren to eller tre dager etter egguttak $(25,26)$.

Man må være klar over at samtlige av de data som så langt er omtalt, har fremkommet i studier hvor det er anvendt rekombinant FSH (22-26). Av klinisk interesse er det derfor viktig å understreke at bruk av urinderivert FSH ikke reduserer sjansen for vellykket graviditet sammenliknet med rekombinant FSH, dersom en GnRH-antagonistprotokoll benyttes (27).

\section{Ultralyd}

Hovedhensikten med ultralydundersøkelser under stimuleringen er å styre veksten av et begrenset antall follikler samtidig som man sikrer en synkron utvikling av endometriet. Om utviklingen av folliklene og endometriet ikke skjer synkront, kan det resultere i en for tidlig modning av endometriet (28-30). Dersom det skjer, er det risiko for at embryoene settes inn i livmoren helt i sluttfasen av implantasjonsvinduet, eller i verste fall at implantasjonsvinduet allerede er passert. Risikoen for å få et for tidlig sekretorisk endometrium øker dersom nivået av LH er høyt i starten av stimuleringen, eller om det går mange dager fra FSH-start til GnRHantagonist gis (30). Forklaringen antas å være at høye nivåer av LH og/eller FSH i tidlig stimuleringsfase fremmer tidlig økt østradiolproduksjon. Et høyt østradiolnivå har en stimulerende effekt på progesteron, noe som igjen resulterer i prematur utvikling av et sekretorisk endometrium (31).

Dersom egguthentingen ikke utføres når folliklene har nådd en viss størrelse, er det også økt risiko for at endometriet er blitt for sekretorisk og følgelig mindre mottakelig for implantasjon av embryoene (32). Dette er blant annet vist $i$ en belgisk studie der implantasjonsraten var signifikant bedre når HCG ble gitt med én gang det var minst tre follikler på $\geq 17 \mathrm{~mm}$ enn når man ventet ytterligere et par dager, på tross av at embryokvaliteten i de to gruppene var den samme (33). 
Hos et lite mindretall kvinner vil erfaringsmessig en adekvat endometrietykkelse ( $\geq 7 \mathrm{~mm}$ ) vanskelig kunne oppnås under stimuleringen ved samtidig bruk av GnRHantagonist. Ved senere behandlinger bør den konvensjonelle GnRH-agonistprotokollen benyttes hos disse kvinnene fordi den er mer fleksibel.

\section{Kliniske aspekter}

Målet med enhver assistert befruktning bør være å gjøre behandlingen så pasientvennlig og kostnadseffektiv som mulig uten å redusere sjansen for vellykket graviditet. Selv om flere studier taler for at bruk av GnRHantagonist er den behandlingsstrategien som best oppfyller disse kriteriene, er et behandlingsregime med GnRH-agonist fortsatt det mest vanlige $(34,35)$. Én viktig årsak til dette er at mange registrerte at graviditetsfrekvensen sank når man forsøkte behandling med GnRH-antagonist, noe som også fremkom i metaanalyser $(34,35)$. Senere er man blitt klar over at årsakene til en lavere graviditetsrate ved bruk av GnRH-antagonist skyldtes at denne strategien oftere ble anvendt hos kvinner med redusert sjanse for graviditet, for eksempel kvinner i høy reproduktiv alder, eller hos kvinner som allerede hadde gjennomgått flere mislykkede behandlinger (35). Dessuten benyttet man til å begynne med i utprøvningen av GnRHantagonist ulike stimuleringsstrategier som resulterte i varierende graviditetsrate. Ser man bort fra disse faktorene, er sjansen for å føde et barn etter in vitro-fertilisering like stor uansett om man benytter en GnRH-agonist eller en GnRH-antagonist (35). Det synes også klart at dersom GnRH-antagonist blir anvendt, kan ikke eggstokkene stimuleres på samme måte som tidligere, noe som hovedsakelig skyldes at dette stimuleringsregimet er mindre fleksibelt enn den tradisjonelle stimuleringsmetoden.

I en nederlandsk studie viste man at sjansen for vellykket graviditet ved gjentatte behandlinger i løpet av ett år var like stor ved mild in vitro-fertilisering, der GnRH-antagonist ble benyttet, som ved tradisjonell GnRH-agonistbehandling (8). Frafallsraten etter to behandlinger var imidlertid signifikant lavere i GnRH-antagonistgruppen sammenliknet med gruppen som fikk tradisjonell behandling. Selv om begge gruppene opplevde behandlingsrelatert ubehag i form av engstelse, psykisk uro, depresjon og søvnproblemer, var det psykiske stressnivået stabilt over tid i GnRH-antagonistgruppen, mens det økte i GnRH-agonistgruppen. Totalkostnadene for behandlingen var drygt $20 \%$ lavere i GnRHantagonistgruppen (8). I et klinisk perspektiv er det også viktig å merke seg at man i en metaanalyse konkluderte med at fem modne egg ved egguthentingen er det optimale antallet for å oppnå høyest mulig implantasjonsrate ved mild in vitro-fertilisering. Implantasjonsraten synker dersom stimuleringen medfører at det høstes flere enn åtte egg (36).
Svakheten ved mild in vitro-fertilisering er imidlertid at man ofte får svært få egg ved egguthentingen. Dermed øker risikoen for at man ikke har egnede embryoer for innsetting i livmorhulen (8).

Selv om det synes klart at anvendelse av GnRH-antagonist er den mest pasientvennlige behandlingsmetoden, har denne strategien flere svakheter sammenliknet med den lange GnRH-agonistprotokollen. Én vesentlig svakhet er hvordan stimuleringsstart skal kunne styres for å få god logistikk av behandlingen og derved blant annet unngå mye helgearbeid. Det har vært gjort forsøk på å programmere stimuleringsstarten ved hjelp av p-piller, noe som viste seg å ha en signifikant negativ effekt på graviditetsraten (37). Tidligere er det vist at østradioltabletter i lutealfasen før stimuleringsstart kan benyttes for å etablere en homogen vekst av folliklene under stimulering ved bruk av $\mathrm{GnRH}$-antagonist uten at denne forbehandlingen reduserer graviditetsraten (38). Nylig viste en fransk studie at østradioltabletter fra 25. syklusdag også kan benyttes for å programmere stimuleringen uten at sjansen for vellykket graviditet synker (39). Dersom resultatene fra denne studien blir bekreftet av andre, innebærer det et stort steg fremover i arbeidet med å kunne programmere stimuleringsstart.

Det synes også klart at den lange GnRHagonistprotokollen bør foretrekkes på grunn av sin fleksibilitet ved behandlinger der det stilles store krav til logistikk, for eksempel ved arbeidskrevende prosedyrer som kirurgisk uthenting av sædceller fra testiklene eller preimplantatorisk genetisk diagnostikk.

Ved tradisjonell stimulering har det vært et mål å høste 10-20 egg for å ha mange embryoer å velge mellom ved innsetting i livmorhulen (40). En slik intensiv stimulering innebærer økt risiko for sideeffekter som oppblåsthet og magesmerter samt komplikasjoner som for eksempel ovarialt hyperstimuleringssyndrom (OHSS). Bruk av GnRHantagonist ser ut til å halvere risikoen for ovarialt hyperstimuleringssyndrom sammenliknet med GnRH-agonistbehandling (34). Ved så å anvende GnRH-agonist i stedet for HCG for å fullføre sluttmodningen av eggene, etter at $\mathrm{GnRH}$-antagonist har vært benyttet under stimuleringen av eggstokkene, kan man i praksis eliminere risikoen for syndromet (41). Denne strategien representerer et stort fremskritt ved in vitro-fertilisering sammenliknet med tradisjonell stimulering.

Både dyreeksperimentelle og humane studier tyder på at intensiv stimulering av eggstokkene har ugunstig effekt på egg- og embryokvaliteten samt det uterine miljøet (42-44). Dessuten taler flere studier for at sjansen til vellykket graviditet ikke er redusert om man stimulerer mindre intensivt enn det som har vært vanlig (45-47). Selv er jeg av den oppfatning at i de fleste tilfeller bør målsetningen med stimuleringen være å få høstet 5-10 modne egg, og at man som
Syklusdag 2

Hormonprofil, dersom $\emptyset$ nskelig

(østradiol, progesteron, LH, FSH)

Syklusdag 2 - 5

Start med daglige FSH-injeksjoner

Syklusdag 5

Start med daglige

$\mathrm{GnRH}$-antagonistinjeksjoner

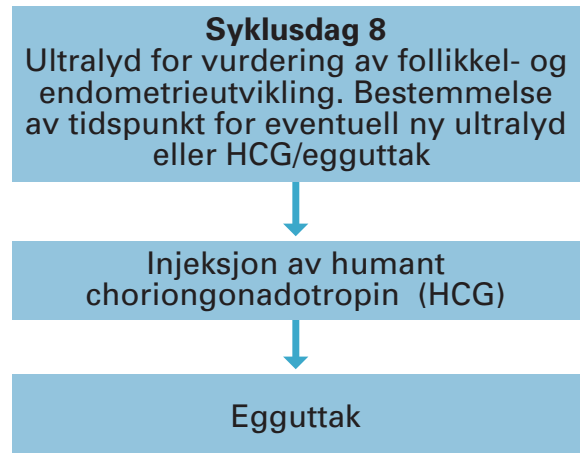

Figur 2 Mal for bruk av GnRH-antagonist ved in vitro-fertilisering. Hormonprofil kan tas på morgenen syklusdag 2 for å utelukke ugunstige hormonnivåer. Injeksjoner med follikkelstimulerende hormon (FSH) gis på kveldstid for å få optimal fleksibilitet av stimuleringen. Injeksjoner med GnRH-antagonist gis fra og med syklusdag 5 for blant annet å sikre at nivået av luteiniserende hormon (LH) holder seg lavt i tidlig fase av stimuleringen. Antagonistinjeksjonene gis på mor genen for å sikre optimal effekt og etterlevelse. Den første ultralydundersøkelsen for å vurdere follikkelog endometrieutvikling giøres på syklusdag 8, men kan gjøres på syklusdag 7 eller 9 om syklusdag 8 er på en helgedag. Ultralyd på et tidligere tidspunkt under stimuleringen gir erfaringsmessig lite informasjon av kliniske verdi i de fleste tilfeller

oftest kan starte med GnRH-antagonist på syklusdag 5 (fig 2).

\section{Konklusjon}

En mindre intensiv stimulering enn det som har vært vanlig, der man starter med GnRHantagonist på et tidlig tidspunkt, innebærer en like høy graviditetsrate, men færre bivirkninger, mindre risiko for komplikasjoner og lavere behandlingskostnader enn det tradisjonelle behandlingsregimet med GnRHagonist. En slik strategi resulterer også i mindre arbeidsbelasting for de som er involvert $\mathrm{i}$ behandlingen, ikke minst laboratoriepersonalet. Erfaringsgrunnlaget ved bruk av GnRH-antagonist er nå så omfattende at denne stimuleringsmetoden bør bli et førstevalg. Den største svakheten ved GnRHantagonist er at dette regimet er mindre fleksibelt, noe som blant annet innebærer mer arbeid for helsepersonalet i helger og på høytidsdager. 


\section{Erling Ekerhovd (f. 1958)}

er dr.med. og spesialist i fødselshjelp og kvinnesykdommer. Han er gynekolog ved Medicus og førsteamanuensis ved Sahlgrenska akademiet, Göteborgs universitet.

Oppgitte interessekonflikter: Har mottatt honorar for forelesninger samt deltatt i møter, kurs og kongresser som har vært sponset av følgende legemiddelfirmaer som alle har medikamenter som benyttes ved in vitro-fertilisering: MSD (tidligere Schering-Plough), Merck Serono (tidligere Serono) og Ferring Legemidler.

\section{Litteratur}

1. Land JA, Courtar DA, Evers JL. Patient dropout in an assisted reproductive technology program: implications for pregnancy rates. Fertil Steril 1997; 68: $278-81$

2. Schröder AK, Katalinic A, Diedrich K et al. Cumulative pregnancy rates and drop-out rates in a German IVF programme: 4102 cycles in 2130 patients. Reprod Biomed Online 2004; 8: 600-6.

3. Olivius K, Friden B, Lundin $\mathrm{K}$ et al. Cumulative probability of live birth after three in vitro fertilization/intracytoplasmic sperm injection cycles. Fertil Steril 2002; 77: 505-10.

4. Rajkhowa M, McConnell A, Thomas GE. Reasons for discontinuation of IVF treatment: a questionnaire study. Hum Reprod 2006; 21: 358-63.

5. Verberg MF, Eijkemans MJ, Heijnen EM et al. Why do couples drop-out from IVF treatment? A prospective cohort study. Hum Reprod 2008; 23 2050-5.

6. Brandes M van der Steen JO, Bokdam SB et at. When and why do subfertile couples discontinue their fertility care? A longitudinal cohort study in a secondary care subfertility population. Hum Reprod 2009: 24: 3127-35.

7. de Klerk C, Macklon NS, Heijnen EM et al. The psychological impact of IVF failure after two or more cycles of IVF with a mild versus standard treatment strategy. Hum Reprod 2007; 22: 2554-8.

8. Heijnen EM, Eijkemans MJ, De Klerk $C$ et al. A mild treatment strategy for in-vitro fertilisation: a randomised non-inferiority trial. Lancet 2007; 369: 743-9

9. Pennings $G$, Ombelet W. Coming soon to your clinic: patient-friendly ART. Hum Reprod 2007. 22: $2075-9$

10. Devroey P, Aboulghar M, Garcia-Velasco J et al. Improving the patient's experience of IVF/ICSI: a proposal for an ovarian stimulation protocol with GnRH antagonist co-treatment. Hum Reprod 2009; 24: $764-74$

11. Huirne JA, Lambalk CB. Gonadotropin-releasinghormone-receptor antagonists. Lancet 2001; 358: 1793-803

12. Kolibianakis EM, Albano C, Kahn J et al. Exposure to high levels of luteinizing hormone and estradiol in the early follicular phase of gonadotropin-releasing hormone antagonist cycles is associated with a reduced chance of pregnancy. Fertil Steril 2003; 79: 873-80

13. Lainas T, Zorzovilis J, Petsas $G$ et al. In a flexible antagonist protocol, earlier, criteria-based initiation of $\mathrm{GnRH}$ antagonist is associated with increased pregnancy rates in IVF. Hum Reprod 2005; 20 : 2426-33.

14. Devroey P, Boostanfar R, Koper NP et al. A double-blind, non-inferiority RCT comparing corifollitropin alfa and recombinant FSH during the first seven days of ovarian stimulation using a GnRH antagonist protocol. Hum Reprod 2009; 24: $3063-72$.

15. Corifollitropin alfa for ovarian stimulation in IVF: andomized trial in lower-body-weight women. Reprod Biomed Online 2010; 21: 66-76.

16. Albano C, Felberbaum RE, Smitz J et al. Ovarian stimulation with HMG: results of a prospective randomized phase III European study comparing the luteinizing hormone-releasing hormone (LHRH)-antagonist cetrorelix and the LHRH-agonist buserelin. Hum Reprod 2000; 15: 526-31.
17. Borm G, Mannaerts B. Treatment with the gonadotrophin-releasing hormone antagonist ganirelix in women undergoing ovarian stimulation with recombinant follicle stimulating hormone is effective, safe and convenient: results of a controlled, randomized, multicentre trial. Hum Reprod 2000; 15: $1490-8$.

18. European and Middle East Orgalutran Study Group. Comparable clinical outcome using the $\mathrm{GnRH}$ antagonist ganirelix or a long protocol of the $\mathrm{GnRH}$ agonist triptorelin for the prevention of premature LH surges in women undergoing ovarian stimulation.. Hum Reprod 2001; 16: 644-51.

19. Fluker M, Grifo J, Leader A et al. Efficacy and safety of ganirelix acetate versus leuprolide acetate in women undergoing controlled ovarian hyperstimulation. Fertil Steril 2001; 75: 38-45

20. Nargund G, Fauser BC, Macklon NS et al. The ISMAAR proposal on terminology for ovarian stimulation for IVF. Hum Reprod 2007; 22: 2801-4.

21. Verberg MF, Macklon NS, Nargund G et al. Mild ovarian stimulation for IVF. Hum Reprod Update 2009: 15: 13-29

22. Kolibianakis EM, Zikopoulos K, Smitz J et al. Elevated progesterone at initiation of stimulation is associated with a lower ongoing pregnancy rate after IVF using $\mathrm{GnRH}$ antagonists. Hum Reprod 2004: 19: 1525-9.

23. Kolibianakis EM, Albano C, Kahn J et al. Exposure to high levels of luteinizing hormone and estradiol in the early follicular phase of gonadotropinreleasing hormone antagonist cycles is associated with a reduced chance of pregnancy. Fertil Steril 2003; 79: 873-80

24. Kolibianakis EM, Zikopoulos K, Schiettecatte J et al. Profound LH suppression after GnRH antagonist administration is associated with a significantly higher ongoing pregnancy rate in IVF. Hum Reprod 2004; 19: 2490-6.

25. Bosch E, Valencia I, Escudero E et al. Premature luteinization during gonadotropin-releasing hormone antagonist cycles and its relationship with in vitro fertilization outcome. Fertil Steril 2003; 80: 1444-9

26. Papanikolaou EG, Kolibianakis EM, Pozzobon C et al. Progesterone rise on the day of human chorionic gonadotropin administration impairs pregnancy outcome in day 3 single-embryo transfer. while has no effect on day 5 single blastocyst transfer. Fertil Steril 2009; 91: 949-52.

27. Bosch E, Vidal C, Labarta E et al. Highly purified hMG versus recombinant FSH in ovarian hyperstimulation with $\mathrm{GnRH}$ antagonists-a randomized study. Hum Reprod 2008; 23: 2346-51.

28. Marchini M, Fedele L, Bianchi S et al. Secretory changes in preovulatory endometrium during controlled ovarian hyperstimulation with buserelin acetate and human gonadotropins. Fertil Steril 1991; 55: 717-21.

29. Ubaldi F, Bourgain C, Tournaye $\mathrm{H}$ et al. Endometrial evaluation by aspiration biopsy on the day of oocyte retrieval in the embryo transfer cycles in patients with serum progesterone rise during the follicular phase. Fertil Steril 1997; 67: 521-6.

30. Kolibianakis E, Bourgain C, Albano C et al. Effect of ovarian stimulation with recombinant folliclestimulating hormone, gonadotropin releasing hormone antagonists, and human chorionic gonadotropin on endometrial maturation on the day of oocyte pick-up. Fertil Steril 2002: 78: 1025-9.

31. Jacobs MH, Balasch J, Gonzalez-Merlo JM et al. Endometrial cytosolic and nuclear progesterone receptors in the luteal phase defect. J Clin Endocrinol Metab 1987; 64: 472-5.

32. Kolibianakis EM, Bourgain C, Papanikolaou EG et al. Prolongation of follicular phase by delaying hCG administration results in a higher incidence of endometrial advancement on the day of oocyte retrieval in $\mathrm{GnRH}$ antagonist cycles. Hum Reprod 2005; 20: 2453-6.

33. Kolibianakis EM, Albano C, Camus M et al. Prolongation of the follicular phase in in vitro fertilization results in a lower ongoing pregnancy rate in cycles stimulated with recombinant follicle-stimulating hormone and gonadotropin-releasing hormone antagonists. Fertil Steril 2004; 82: 102-7.

34. Al-Inany HG, Abou-Setta AM, Aboulghar M. Gonadotrophin-releasing hormone antagonists for assisted conception: a Cochrane review. Reprod Biomed Online 2007; 14: 640-9.

35. Kolibianakis EM, Collins J, Tarlatzis BC et al.
Among patients treated for IVF with gonadotro phins and $\mathrm{GnRH}$ analogues, is the probability of live birth dependent on the type of analogue used? A systematic review and meta-analysis. Hum Reprod Update 2006; 12: 651-71.

36. Verberg MF, Eijkemans MJ, Macklon NS et al. The clinical significance of the retrieval of a low number of oocytes following mild ovarian stimulation for IVF: a meta-analysis. Hum Reprod Update 2009: 15: 5-12.

37. Griesinger G, Kolibianakis EM, Venetis $C$ et al. Oral contraceptive pretreatment significantly reduces ongoing pregnancy likelihood in gonadotropinreleasing hormone antagonist cycles: an updated meta-analysis. Fertil Steril 2010; 94: 2382-4.

38. Fanchin R, Salomon L, Castelo-Branco A et al. Luteal estradiol pre-treatment coordinates follicular growth during controlled ovarian hyperstimulation with $\mathrm{GnRH}$ antagonists. Hum Reprod 2003; 18 2698-703.

39. Guivarc'h-Levêque A, Arvis P, Bouchet JL et al. Efficacité de la programmation des cycles FIV en antagonistes par les estrogènes. Gynecol Obstet Fertil 2010; 38: 18-22.

40. Fauser BC, Devroey P, Yen SS et al. Minimal ovarian stimulation for IVF: appraisal of potential benefits and drawbacks. Hum Reprod 1999: 14: 2681-6.

41. Humaidan P. Kol S, Papanikolaou E. GnRH agonist for triggering of final oocyte maturation: time for a change of practice? Hum Reprod Update 2011; 17: $510-24$

42. Ertzeid G. Storeng R. The impact of ovarian stimulation on implantation and fetal development in mice. Hum Reprod 2001; 16: $221-5$.

43. Baart EB, Martini E, Eijkemans MJ et al. Milder ovarian stimulation for in-vitro fertilization reduces aneuploidy in the human preimplantation embryo: a randomized controlled trial. Hum Reprod 2007; 22: 980-8.

44. Xu YW, Peng YT, Wang B et al. High follicle-stimulating hormone increases aneuploidy in human oocytes matured in vitro. Fertil Steril 2011; 95 : 99-104.

45. Wikland M, Bergh C, Borg K et al. A prospective, randomized comparison of two starting doses of recombinant FSH in combination with cetrorelix in women undergoing ovarian stimulation for IVF/ICSI. Hum Reprod 2001; 16: 1676-81.

46. Sterrenburg MD, Veltman-Verhulst SM, Eijkemans $\mathrm{MJ}$ et al. Clinical outcomes in relation to the daily dose of recombinant follicle-stimulating hormone for ovarian stimulation in in vitro fertilization in presumed normal responders younger than 39 years: a meta-analysis. Hum Reprod Update 2011 17: $184-96$

47. Nelson SM, Yates RW, Lyall H et al. Anti-Müllerian hormone-based approach to controlled ovarian stimulation for assisted conception. Hum Reprod 2009; 24: 867-75

Mottatt 25.4. 2010, første revisjon innsendt 13.7. 2010, godkjent 3.3. 2011. Medisinsk redaktør Trine B. Haugen. 